\title{
Religiosity, Social Stigma, and Public Acceptance to People Living with HIVIAIDS among Citizens in Bandung, Indonesia
}

\author{
Angga Wilandika ${ }^{1 *}$ (D) Suzanna Yusof $^{2}$ D, Diah Nur Indah Sari ${ }^{3}$ iD \\ ${ }^{1}$ Department of Nursing, Universitas Aisyiyah Bandung, Bandung, Indonesia; ${ }^{2}$ Centre for Nursing Studies, Universiti Teknologi \\ MARA, Shah Alam, Malaysia; ${ }^{3}$ Department of Public Health, Universitas Aisyiyah Bandung, Bandung, Indonesia
}

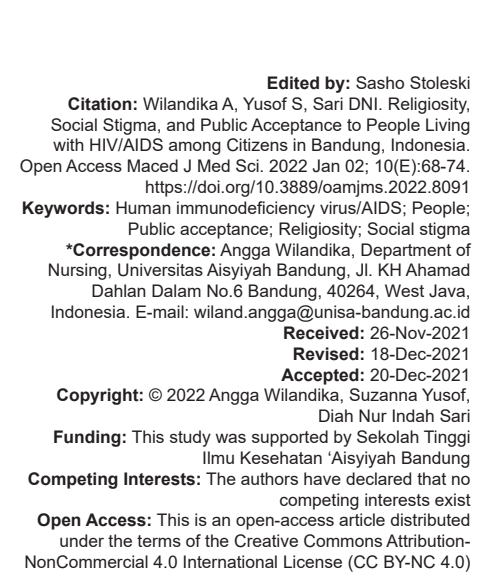

\section{Introduction}

Human immunodeficiency virus (HIV) infection cases increase every year in Indonesia. The number of HIV cases from 2018 to 2019 has increased by $17.1 \%$. In 2018 , the number of cases reported was 46,650 , increasing to 50,282 cases in December 2019. West Java Province occupies the third position after DKI Jakarta and East Java, with the highest HIV infections in Indonesia, 45,881 cases [1]. Meanwhile, Bandung is the city with the highest HIV cases compared to other cities in West Java.

The AIDS epidemic occurs accompanied by adverse reactions or social stigma against people with HIV infection. The social stigma that formed from the aspects of knowledge (labeling), attitudes (prejudice), and behavior (discrimination) [2] is a severe problem. The stigma that occurs to people living with HIV/ AIDS (PLWHA) can be a form of excessive prejudice, negative attitudes, and inadequate treatment directly from the people around them.
The stigma against HIV disease threatens the physical and psychological well-being of PLWHA. The stigma also impacts on ability and willingness of the community to provide treatment and care for PLWHA and the prevention of further HIV transmission. Stigma is also a significant barrier to accessing prevention, care, and care services [3], [4].

The stigma causes people with HIV reluctance not to disclose their HIV-positive status, thereby delaying access to the treatment [5]. Stigma can damage a person's identity and capacity to cope with the disease. Fear of discrimination limits the possibility of disclosing status and discourages potential endorsements such as family and friends. With stigma, people infected by HIV and those thought to be infected with HIV experience social exclusion, discrimination, and even violence. Zierler et al. (2000), in their study, reported that people with HIV-positive status experienced acts of physical violence from the time they were diagnosed.

The impact of the social stigma that arises from the community makes it difficult for PLWHA to reach broadly into the community, disrupts community 
functions, and makes HIV prevention and treatment difficult. This HIV-related stigma is considered a sustainable and destructive problem in every aspect of community, social, and economic life. The social stigma against PLWHA not only makes life more difficult but is related to the development of the HIVIAIDS epidemic at large. This situation occurs due to systematic stigma emerging from households, communities, work environments, health services, and the government.

Various ways and approaches must take when a disease is stigmatized to suppress the stigmatization. However, many stigmas appear against HIV from people who have a good education, economy, and religious knowledge. A disease that has been stigmatized will complicate the acceptance of the sufferer.

Religion and spirituality about the life of a person with HIV are expected to play a significant role. Religiosity and reduced risk of disease have a significant relationship. This linkage is because religious values and beliefs are the main factors in protecting against disease. PLWHA combines religiosity to solve problems, helps reorganize lives, and get meaning and purpose in life. Religious experiences help them interpret the problems and situations due to HIV disease. The situations they encounter are often considered unfavorable for them, such as incidents of stigmatization [6].

However, it is different from the research results of Muturi and An [7], who found that people who have high religiosity show a high stigma against people with HIVIAIDS. This high stigma is associated with the assumption that HIVIAIDS is a curse and punishment from God. Verbal responses to open-ended questions also reveal that widespread prejudice comes from a religious point of view. High religiosity is a significant factor in determining the high stigma of PLWHA.

Thus, it is essential to examine the relationship between perceived religiosity by society and the social stigma that may occur in society toward PLWHA. It can also see the relationship between the levels of religiosity with public acceptance of PLWHA. The purpose of this study is to determine the correlation between religiosity with social stigma and public acceptance of PLWHA.

\section{Methods}

The research design used was cross-sectional with a convenience sampling technique. This design was used to identify a relationship between religiosity, social stigma, and public acceptance of people with HIVIAIDS. The respondents involved were 400 people living in the city of Bandung and recorded as resident who already has a National Identity Card. Respondents aged between 17 years and 65 years could answer every question. The subjects were not people with HIVIAIDS, but knowing what HIVIAIDS is and even having met or known there are people with HIV in the environment. The data collection was carried out using an online form.

The research instrument used was the Indonesian HIVIAIDS social stigma (I-HSS) scale [8]. The I-HSS scale was used to measure the social stigma in society. The I-HSS scale consists of 25 items, measures social stigma based on three stigma domains: Neglect/labeling, prejudice, and discrimination. This scale has proven validity and reliability values. The construct validity scores of the overall items in the I-HSS scale ranged from 0.52 to 0.84 .

Meanwhile, the internal consistency or reliability score for the I-HSS scale is 0.75 . Meanwhile, the measurement of the aspect of public acceptance of people with HIVIAIDS uses the scale of public acceptance of people with HIVIAIDS. This instrument consists of 11 questions. The public acceptance scale assesses treatment, support, cooperation, and public trust. This scale has a valid value between 0.427 and 0.856 and reliability of the scale of 0.778 .

In addition, this study also uses the centrality of religiosity scale (CRS) [9] to know the level of someone's religiosity. This CRS instrument has been modified in Indonesian, consisting of 14 questions [10]. The instrument consists of ideology, intellectual, private practice, public practice, and religious experience. Validity for each dimension is: Ideology 0.620 , intellectual 0.659 , private practice 0.801 , public practice 0.822 , and religion experience 0.727 . The reliability value of this scale is 0.853 .

The correlation test used to answer the research hypothesis used the non-parametric test and the Spearman's rank, both for the correlation test of the religiosity variable with social stigma and public acceptance. This test was carried out because one of the variables tested with an interval scale was not normally distributed. The study was approved by the Health Research Ethics Committee at Sekolah Tinggi IImu Kesehatan 'Aisyiyah Bandung Nomor 19/KEP.02/ STIKes-AB/VII/2019. 
The result for religiosity, social stigma, and public acceptance is shown in Table 1. Table 2 shows the relationship between stigma and public acceptance of religiosity. Table 1 shows that respondents' religiosity was mainly high (96.5\%). Most respondents obtained not good public acceptance (54.7\%), and also that the stigma obtained was high (58.7\%). Table 2 revealed that social stigma and public acceptance were related to religiosity $(p=0.001$ and $p=0.001$, respectively, with $\alpha=0.05$ ). Social stigma positively correlated with religiosity, whereas public acceptance correlated positively with religiosity. These results showed that high social stigma and good public acceptance are associated with high religiosity.

Table 1: Religiosity, social stigma, and public acceptance among citizens in Bandung, Indonesia

\begin{tabular}{llll}
\hline Characteristics & $\begin{array}{c}\text { Average Score } \\
(\text { Mean } \pm \text { SD) }\end{array}$ & $\mathrm{f}$ & $\%$ \\
\hline Religiosity & $38.4 \pm 5.3$ & 386 & 96.5 \\
$\quad$ Religious & & 14 & 3.5 \\
$\quad$ Less religious & & & \\
Social Stigma & & 235 & 58.7 \\
$\quad$ High & $80.1 \pm 24.0$ & 165 & 41.3 \\
$\quad$ Low & & & \\
Public Acceptance & $35.1 \pm 10.2$ & 181 & 45.3 \\
$\quad$ Good & & 219 & 54.7 \\
$\quad$ Not good & & & \\
\hline
\end{tabular}

Tables 3 and 4 show a picture of social stigma and public acceptance of society based on its forming aspects. Table 3 shows that some people's prejudice and discrimination are still high. The negative prejudice of the community toward PLWHA reached $57.7 \%$, and the discriminatory aspect also reached $50.8 \%$. However, in terms of community HIV neglect or labeling, it is $45.7 \%$. Meanwhile, that public acceptance is based on four aspects: The desire to accept the existence of PLWHA in the community has only reached $46 \%$. The aspects of community support, cooperation, and trust for people living with HIV are also quite good, reaching $53.5 \%, 57.5 \%$, and $55.8 \%$, respectively (Table 4 ).

Table 2: Relationship between religiosity with social stigma and public acceptance among citizens in Bandung, Indonesia $(n=400)$

\begin{tabular}{lll}
\hline Variables & Religiosity & \\
\cline { 2 - 3 } & Correlation coefficient & Sig. (2-tailed) \\
\hline Social Stigma & 0.325 & 0.001 \\
Public Acceptance & 0.506 & 0.001 \\
\hline
\end{tabular}

\section{Discussion}

There was a positive correlation between community religiosity and Spearman's correlation

Table 3: Aspects of social stigma against PLWHA among citizens in Bandung, Indonesia $(n=400)$

\begin{tabular}{llll}
\hline Aspects of Social Stigma & $\begin{array}{l}\text { Average Score } \\
\text { (Mean } \pm \text { SD) }\end{array}$ & f & $\%$ \\
\hline $\begin{array}{l}\text { Neglect/Labeling } \\
\quad \text { High }\end{array}$ & $24.7 \pm 8.4$ & 183 & 45.7 \\
$\quad$ Low & & 217 & 54.3 \\
$\begin{array}{l}\text { Prejudice } \\
\quad \text { High }\end{array}$ & $30.6 \pm 11.0$ & & \\
$\quad$ Low & & 230 & 57.5 \\
Discrimination & $24.9 \pm 8.9$ & 170 & 42.5 \\
$\quad$ High & & 203 & 50.8 \\
$\quad$ Low & & 197 & 49.3 \\
\hline PLWHA: People living with HIV/AIDS. & & &
\end{tabular}

coefficient of 0.325 and 0.506 for social stigma and public acceptance toward PLWHA, respectively, $(p<0.05)$. The level of community religiosity is almost entirely religious $(96.5 \%)$. Meanwhile, society's social stigma is mainly high (58.7\%), but the public acceptance is low mainly $(54.7 \%)$.

The results of this study indicate an inline pattern of the effect of religiosity on stigma. Someone who has high religiosity will have a high social stigma towards PLWHA. The results of this study are similar to research by Muturi and An [7], where religiosity and stigma have a significant relationship but have a positive direction. People with high religiosity show a much higher stigma. This high stigma is associated with curses and punishment from God for people with HIV/ AIDS. In addition, there was also a profound prejudice against HIVIAIDS from a religious perspective.

The link between HIV and immoral behavior arises from a religious perspective. The assumption that HIV infection is a consequence of committed sins still appears in society. Even in some societies, religious and moral values make people think that HIV infection results from moral wrongdoing (promiscuity or deviant sex) and deserves punishment. That assumption shows that there are times when a high level of religiosity can lead to high stigmatization of HIV infection.

When people make religious attributes based on the assumption of sinful and immoral behavior, the stigma on HIV becomes higher, which causes public acceptance of PLWHA to decrease. Such stigma based on religiosity would not only discredit PLWHA but justify their suffering in the name of "punishment" or "curse".

However, on the other hand, the involvement of religiosity in the health sector cannot be denied. The relationship of religiosity with HIV disease is also very close. Religious activities (such as prayer, spiritual studies, and reading religious literature) were significantly associated with immunity status in patients with HIV, as indicated by an increase in CD4 + counts in the body [11]. Likewise, religiosity, social stigma, and public acceptance of HIV have significant links.

The role of religiosity concerning the life of someone who has a severe illness is quite significant. Religiosity impacts reducing the risk of illness that a

Table 4: Aspects of Public Acceptance toward PLWHA among Citizens in Bandung, Indonesia $(n=400)$

\begin{tabular}{llll}
\hline Aspects of public acceptance & $\begin{array}{l}\text { Average Score } \\
\text { (Mean } \pm \text { SD) }\end{array}$ & $\mathrm{f}$ & $\%$ \\
\hline Accept the existence & $15.2 \pm 5.5$ & 184 & 46.0 \\
$\quad$ Yes & & 216 & 54.0 \\
$\quad$ Not & $6.5 \pm 2.6$ & 214 & 53.5 \\
Support & & 186 & 46.5 \\
$\quad$ Yes & $6.5 \pm 2.6$ & & \\
$\quad$ Not & & 230 & 57.5 \\
Cooperation & & 170 & 42.5 \\
Yes & $7.0 \pm 2.0$ & & \\
$\quad$ Not & & 223 & 55.8 \\
Trust & & 177 & 44.3 \\
$\quad$ Yes & & & \\
Not & & & \\
\hline PLWHA: People living with HIV/AIDS. & & & \\
\end{tabular}


person may suffer. Even studies reveal that people diagnosed with HIV experience increased spirituality and religion [12]. Ironson et al. [13] stated that high spirituality results in decreased cortisol levels, thus reducing levels of depression and hopelessness. In addition, it also causes smoking habits that tend to decline and an increase in the quality of life.

The people of Bandung City are dynamic societies, developing along with the changing times. Various cultures mingle with each other and interact with the citizens of the city of Bandung. The variety of cultures brought by newcomers to Bandung City is also a distinctive color that makes Bandung City more attractive. Likewise, the various religions practiced by the citizens of the city of Bandung make the atmosphere of the city of Bandung livelier. Even though most residents embrace Islam, other religions can still develop and worship peacefully.

Religion is a belief or faith that is held firmly by its adherents. Religion is also a system and rituals of worship that regulate individual relationships with God Almighty. Religion is also able to move someone to behave and act. The level of piety or religiosity assesses the indicator of someone having a solid religion. A society with a good level of religiosity impacts the development of that society in a better direction.

The results of this study indicate that almost all residents of Bandung City have a good level of religion or are in the religious category (96.5\%). Even though most people involved in this study are Muslim $(91.8 \%)$, this does not change the fact that the citizens of Bandung with various religions involved in this study are religious.

Aperson's religiosity is not easy to learn or even see. Religiosity is a multidimensional. The religiosity aspect varies from person to person. Religiosity has five dimensions: Religious belief, religious practice, the experience of appreciation, consequential, and worship observance [14]. Religiosity is not only the visible activities but those that are not visible and must be characterized as personal or can only be felt in one's heart. In other words, religiosity appears in rituals and physical worship, but there are many invisible forms of worship related to belief and obedience to God Almighty.

Religiosity is also closely related to one's views, perceptions, interpretations, and behavior of a case. As Beit-Hallahmi [15] stated, religion aims to measure religious thoughts and meaning. It refers to hypotheses, explanations, religious ideas, and actions in psychological terms. Religiosity encompasses various human activities in various fields of life, be it the social, economic, or even health fields. Religiosity has a dominant impact on changes in health behavior. People with citizens who have a high level of religiosity tend to be more careful in responding to various problems or activities prohibited by their religion. So that the various problems faced or that arise amid the community will be able to be faced by relying on their spiritual strength. In other words, various worldly problems can be resolved by placing religion as a reference or reference for solving these problems.

The HIV infection epidemic raises health and social problems that are difficult to treat. This problem is the stigma of PLWHA. Goffman [16] says that the term stigma comes from Greek. Stigma is a term that refers to signs from the body to reveal something unusual or not suitable as a marker of a person's moral status. A sign of an incision scar on the body is identified as a sign of a slave or criminal. So that stigma is interpreted as an attribute that significantly discredits someone to become tarnished or dirty.

Initially, HIVIAIDS, which mainly occurs in perpetrators of unhealthy sexual relations, has become a marker for society to think that HIVIAIDS is something dirty. People are exposed to this information, the longer they will believe and be convinced of this assumption. As stated by Goffman that the stigmatization of society occurs based on so-called "differences" or "deviations" and results in a "bad identity".

Meanwhile, Thornicroft et al. [17] stated that a stigma is an act of giving social labels or signs that give rise to negative attitudes and aim to discredit someone. In addition, stigma is also defined as a negative perception that a person or group uses in perceiving a different situation in a negative sense. Then, it will be used as a norm for a person or group. Stigma is closely related to neglect, prejudice, and discrimination.

The study results on the social stigma of PLWHA among the citizens of Bandung City showed that the social stigma of HIV was mainly high (58.7\%), with a mean score of $80.1 \pm 24.0$. The stigma of HIV/ AIDS, which is measured in Bandung City residents, is seen from three aspects of the problem, namely, the problem of knowledge (neglect/labeling, the problem of negative attitudes (prejudice), and the problem of rejection behavior (discrimination). In this study, it can be seen that some people are still at a high level in terms of prejudice and discrimination, judging by the area of social stigma. Negative public prejudice against PLWHA reached $57.7 \%$ and discrimination reached $50.8 \%$. However, in terms of ignoring or labeling PLWHA in the community, it is $45.7 \%$.

Knowledge problems that give rise to stigma in PLWHA are neglect or labeling. Ignoring or labeling is someone's action to ignore people with HIV disease and give a negative label. This action occurs based on the person's knowledge of HIV. HIVIAIDS infection is considered a disorder, occurs due to the wrong conception of knowledge, and is misunderstood by most people. The wrong conception of knowledge will broaden and assume that people with HIVIAIDS infection are different. If believed by the majority of the community, this attitude will lead to labeling and stereotyping of groups of people with HIVIAIDS. 
This misconception of knowledge arises from incorrect beliefs about the transmission of HIV infection. Most people understand that HIV is transmitted through unsafe sexual relations and sharing needles with drug users. However, not many people know how HIV infection is transmitted, and not many people also know that HIV infection is not easily transmitted. That statement supported by Fauk et al. [18] that the stigma of HIV occurs because of a lack of knowledge about the disease. This HIV stigma is also strengthened by the emergence of negative feelings toward people with HIVIAIDS, discomfort and avoidance, and the wrong conception of knowledge related to HIV transmission.

In addition, the understanding that is widely developed in society is that people with HIVIAIDS come from groups that are considered socially deviant, such as commercial sex workers, transgender women, men who have sex with men (MSM), and other abnormal behaviors. That understanding gives rise to a broad judgment from society. Most people think that PLWHA deserves to be infected with HIV as a reward for their deviant actions. All of this arises due to inaccurate information about HIVIAIDS.

The prejudice, which is a problem of negative attitudes toward PLWHA, is a burden that can affect the psychosocial status of PLWHA and will develop into discriminatory behavior toward PLWHA. Nelson [19], expressing prejudice, is believed to contribute to disparities in health services for PLWHA. Meanwhile, Stuber et al. [20] said that experiences of prejudice include exposure to negative attitudes, interpersonal discrimination, unfair treatment, and violence experienced by a group of people who are considered different.

Prejudice can be defined as a negative perception that develops in someone with HIV. Prejudice against PLWHA in various areas is characterized by negative emotions and feelings. Prejudice is higher in areas with the most HIV epidemics. This HIV-related prejudice will raise behavioral problems, namely, discrimination against PLWHA and more severe health problems [21].

Meanwhile, discrimination which includes behavioral problems is the act or behavior of a person discriminating against people with HIV disease at every possible opportunity. Discrimination appears as a behavioral response due to stereotypes and excessive prejudice in groups considered socially different by the majority group. There are many incidents of discrimination against PLWHA, both by the general public and by health workers.

The stigma of PLWHA is a social problem. However, this stigma affects the health problems of people with HIV and the overall treatment of HIV infection. The stigma against HIV impacts changing the life habits of PLWHA and reducing their health status. Several studies have revealed various cases of stigma affecting health practices [22], [23].
The stigma against HIV affects PLWHA's access to care facilities. Stigmatized PLWHA will be reluctant to seek treatment for fear of confronting society. Moreover, the unfriendly attitude of health workers and sometimes rejecting HIV care makes it an unpleasant experience for PLWHA. This fear and feeling of discrimination caused PLWHA to stop the treatment process. Meanwhile, discontinuation of antiretroviral therapy experienced by PLWHA will increase the potential for further transmission [24], [25].

In addition, stigma is a complex problem and a significant obstacle in the complete response to HIVIAIDS. If not controlled, the stigma that appears as a social response to the rejection of HIVIAIDS infection can have a broad impact on the deterioration of the quality of health care for people with HIV and the prevention of HIV infection. However, Mahajan et al. [26] stated that efforts to reduce stigma against PLWHA are, on average, at the lowest priority. The characteristics of stigma problems are very complex, involving some fields and various elements. However, if efforts to reduce the stigma are not optimal, it can hamper combating HIVIAIDS infection.

The social stigma that occurs in HIV triggers the rejection of HIV in the community. The study results on public acceptance of PLWHA among the citizens of Bandung showed that the acceptance of community members to PLWHA is low. Most of the community members do not accept the presence of PLWHA in their environment $(54.7 \%)$. Meanwhile, public acceptance can be viewed from four aspects. The desire to embrace the existence of PLWHA in the community reached $46 \%$. Support, cooperation, and public trust for PLWHA are also quite good at $53.5 \%, 57.5 \%$, and $55.8 \%$, respectively.

Acceptance of society is determined by accepting existence and difference, support, cooperation, and trust. HIV disease that is considered different is a factor in the emergence of reluctance to accept the presence of HIV. Acceptance in the community environment becomes neglected because of the pessimistic assumption of HIV. HIV, which some people consider an awful disease or even should be ostracized, makes HIV a sufferer is also not considered a whole individual who has the right to live together in one community. Low recognition will result in high rejection toward PLWHA.

The community's support also influences acceptance of HIV in dealing with the problems encountered [27]. Community acceptance of HIV is tied to environmental support. This support can come from family, friends, neighbors, and coworkers. The supportive environment for HIV affects the prognosis of the disease and the course of the treatment [28]. Nevertheless, PLWHA will likely have problems related to medication and care of the disease without this support. 
Cooperation with PLWHA with all community members and the community's believes that PLWHA does not intentionally transmit the disease is essential aspects of public acceptance. Indeed, if the suspicion of HIV is still hostile, it is difficult to carry out these aspects of acceptance. In addition, the knowledge and ability to understand HIV also influence acceptance. Bidaki et al. (2016) showed that HIV-infected patients who gained acceptance from those around them impacted a better quality of life.

\section{Conclusions}

The social stigma and public acceptance of PLWHA among the citizens of Bandung show that the social stigma of community members was high with low public acceptance in accepting PLWHA in their environment. However, religiosity, social stigma, and public acceptance of HIV have a significant relationship. This stigma was a complex problem and a significant obstacle to handling HIVIAIDS. If not controlled, that problems could vastly impact the deterioration of health care quality for people with HIV and the prevention of HIV infection.

However, efforts to reduce stigma against PLWHA based on religiosity must be a priority. The characteristics of stigma problems are very complex, involving several fields and various elements. Suggestions for further research are the need to develop strategies or interventions for reducing social stigma in society to reduce social stigma in HIV and increase public acceptance.

\section{Acknowledgment}

This research was funded by Sekolah Tinggi Ilmu Kesehatan 'Aisyiyah Bandung, through the research funds with contract number 880/MoU.02/ STIKes-AB/IV/2019. We would also like to express our gratitude to all respondents involved in this research and those who have helped the research.

\section{References}

1. Kementerian Kesehatan RI. Laporan Perkembangan HIV-AIDS and Penyakit Infeksi Menular Seksual (PIMS) Triwulan IV Tahun 2020. Jakarta, Indonesia: Kementerian Kesehatan RI; 2020.

2. Riffel T, Chen SP. Stigma in healthcare? Exploring the knowledge, attitudes, and behavioural responses of healthcare professionals and students toward individuals with mental illnesses. Psychiatr Q. 2020;91(4):1103-19. https://doi. org/10.1007/s11126-020-09809-3

PMid:32789718

3. McMahon CM, Nieman CL, Thorne PR, Emmett SD, Bhutta MF The Inaugural World Report on Hearing: From Barriers to a Platform for Change. New York, United States: Wiley Online Library; 2021.

4. Nyblade L, Stangl A, Weiss E, Ashburn K. Combating HIV stigma in health care settings: What works? J Int AIDS Soc. 2009;12(1):15.

5. Opoku MP, Torgbenu EL, Nketsia W, Mprah WK, Edusei AK. Living with HIV in Ghana: Disclosure of status and experiences of persons receiving antiretroviral therapy. Afr J AIDS Res. 2021;20(3):204213. https://doi.org/10.2989/16085906.2021.1964546 PMid:34517791

6. Inglehart RF. Religion's Sudden Decline: What's Causing it, and What Comes Next? USA: Oxford University Press; 2021.

7. Muturi N, An S. HIVIAIDS stigma and religiosity among African American women. J Health Commun. 2010;15(4):388-401. https://doi.org/10.1080/10810731003753125 PMid:20574877

8. Wilandika A, Sari DN. The development and initial validation of the Indonesian HIV social stigma (I-HSS) scale. KEMAS: Public Health J. 2020;16(1):88-92.

9. Huber S, Huber OW. The centrality of religiosity scale (CRS). Religions. 2012;3(3):710-24.

10. Kosasih AV, Sarbini S, Mulyana A. Leisure boredom and religiosity: Influence on internet addiction tendencies. Psympathic. Scientific J Psycho. 2021;8(1):47-56.

11. Woods TE, Antoni MH, Ironson GH, Kling DW. Religiosity is associated with affective and immune status in symptomatic HIV-infected gay men. J Psychosom Res. 1999;46(2):165-76. https://doi.org/10.1016/s0022-3999(98)00078-6 PMid: 10098825

12. Coleman CL, Holzemer WL. Spirituality, psychological wellbeing, and HIV symptoms for African Americans living with HIV disease. J Assoc Nurses AIDS Care. 1999;10(1):42-50. https:// doi.org/10.1016/S1055-3290(06)60231-8

PMid:9934669

13. Ironson G, Stuetzle R, Fletcher MA. An increase in religiousness/spirituality occurs after HIV diagnosis and predicts slower disease progression over 4 years in people with HIV. J Gen Intern Med. 2006;21 Suppl 5:S62-8. https://doi. org/10.1111/j.1525-1497.2006.00648.x PMid:17083503

14. Hassan R. On being religious: Patterns of religious commitment in Muslim societies. Muslim World. 2005;97(3):437-78.

15. Beit-Hallahmi B. Psychological Perspectives on Religion and Religiosity. London, United Kingdom: Routledge; 2014.

16. Goffman E. Stigma: Notes on the management of spoiled identity. New York, United States: Simon and Schuster; 2009.

17. Thornicroft G, Rose D, Kassam A, Sartorius N. Stigma: Ignorance, prejudice or discrimination? $\mathrm{Br} \mathrm{J}$ Psychiatry. 2007;190:192-3. https://doi.org/10.1192/bjp.bp.106.025791 PMid:17329736

18. Fauk NK, Ward PR, Hawke K, Mwanri L. HIV stigma and discrimination: Perspectives and personal experiences of healthcare providers in Yogyakarta and Belu, Indonesia. Front Med (Lausanne). 2021;8:625787. https://doi.org/10.3389/ fmed.2021.625787 PMid:34055824

19. Nelson A. Unequal treatment: Confronting racial and ethnic disparities in health care. J Natl Med Assoc. 2002;94(8):666-8. 
PMid:12152921

20. Stuber J, Meyer I, Link B. Stigma, prejudice, discrimination and health. Soc Sci Med. 2008;67(3):351-7. https://doi.org/10.1016/j. socscimed.2008.03.023

PMid:18440687

21. Parker R. Stigma, prejudice and discrimination in global public health. Cad Saude Publica. 2012;28(1):164-9. https://doi. org/10.1590/s0102-311x2012000100017

PMid:22267076

22. Harris M, Guy D, Picchio CA, White TM, Rhodes T, Lazarus JV. Conceptualising hepatitis C stigma: A thematic synthesis of qualitative research. Int J Drug Policy. 2021;96:103320. https:// doi.org/10.1016/j.drugpo.2021.103320

PMid:34261587

23. Klein $P$, Fairweather AK, Lawn S, Stallman HM, Cammell P Structural stigma and its impact on healthcare for consumers with borderline personality disorder: Protocol for a scoping review. Syst Rev. 2021;10(1):23. https://doi.org/10.1186/ s13643-021-01580-1

PMid:33423674

24. Giordano TP, Gifford AL, White AC Jr., Almazor ME, Rabeneck L, Hartman C, et al. Retention in care: A challenge to survival with HIV infection. Clin Infect Dis. 2007;44(11):1493-9. https://doi. org/10.1086/516778
PMid:17479948

25. Quinn TC, Wawer MJ, Sewankambo N, Serwadda D, Li C Wabwire-Mangen F, et al. Viral load and heterosexual transmission of human immunodeficiency virus type 1. Rakai project study group. N Engl J Med. 2000;342(13):921-9. https:// doi.org/10.1056/NEJM200003303421303

PMid:10738050

26. Mahajan AP, Sayles JN, Patel VA, Remien RH, Sawires SR, Ortiz DJ, et al. Stigma in the HIVIAIDS epidemic: A review of the literature and recommendations for the way forward. AIDS. 2008;22 Suppl 2:S67-79. https://doi.org/10.1097/01. aids.0000327438.13291.62

PMid:18641472

27. Bidaki R, Mousavi SM, Bashardoust N, Ghannad MS, Dashti N Individual factors of social acceptance in patients infected with human immunodeficiency virus (HIV) at the yazd behavioral consultation center in Iran. Int $\mathrm{J}$ High Risk Behav Addict. 2016;5(1):e22243. https://doi.org/10.5812/ijhrba.22243

PMid:27218064

28. Sherr L, Lampe F, Fisher M, Arthur G, Anderson J, Zetler S, et al. Suicidal ideation in UK HIV clinic attenders. Aids. 2008;22(13):1651-8. https://doi.org/10.1097/ QAD.0b013e32830c4804

PMid:18670226 